\title{
Clinicopathological analysis of cervical polyps
}

\section{Ushadevi Gopalan $^{1 *}$, Sathiyakala Rajendiran ${ }^{1}$, Ranganathan Karnaboopathy $^{2}$}

\author{
${ }^{1}$ Department of Obstetrics and Gynecology, ${ }^{2}$ Department of Community Medicine, Shri Sathya Sai Medical College \\ and Research Institute, Ammapettai, Kancheepuram, Tamilnadu, India
}

Received: 03 February 2017

Accepted: 04 March 2017

\section{*Correspondence:}

Dr. Ushadevi Gopalan,

E-mail: ushag7@hotmail.com

Copyright: () the author(s), publisher and licensee Medip Academy. This is an open-access article distributed under the terms of the Creative Commons Attribution Non-Commercial License, which permits unrestricted non-commercial use, distribution, and reproduction in any medium, provided the original work is properly cited.

\begin{abstract}
Background: Cervical polyps are the commonest cervical lesions and occur in about 2-5\% of women. It is common practice to remove these polyps whenever they are identified and the main reason for this is the concern over the potential for malignant transformation. This study was done to analyse the spectrum of histopathological diagnosis in cases of cervical polyps and to identify focus of malignancy if present. This would help us to improve further management of cases of symptomatic and asymptomatic cervical polyps

Methods: This study was conducted in the department of Obstetrics and Gynecology in a tertiary care teaching hospital over a period of two years. Women with a polypoidal growth from the cervix visualized on per speculum examination were included in the study. Polypectomy was done and the specimen sent for histopathological examination and the data analysed.

Results: Total of 107 women was included in the study. Most of the women (47.7\%) were in the age group 40-49 years. Endocervical mucous polyp was found to be the most common lesion $(50.5 \%)$ followed by benign endometrial polyp $(21.5 \%)$, and leiomyomatous polyp in $13.1 \%$. There were no foci of malignancy identified in any of these polyps.

Conclusions: As the incidence of malignancy in endocervical polyp is very low, it is suggested that in cases of asymptomatic polyps, there is a role for expectant management with no intervention and these patients can be followed up leading to significant savings in health resources
\end{abstract}

Keywords: Cervical polpys, Endocervical polyps, Histopathological analysis, Polypectomy

\section{INTRODUCTION}

Cervical polyps are the commonest cervical lesions and occur in about $2-5 \%$ of women ${ }^{1}$. They are usually outgrowths of columnar epithelium of the cervix. They are more frequent in parous women over 20 years of age and most of them (60-70\%) are asymptomatic and found on routine speculum examination of cervix. ${ }^{2-7}$ They can however cause symptoms such as intermenstrual, postcoital and postmenopausal bleeding as well as vaginal discharge. It is common practice to remove these polyps whenever they are identified and the main reason for this is the concern over the potential for malignant transformation. ${ }^{7-10}$ Some researchers also think that regardless of menopausal status or symptoms, uterocervical polyps should be removed and pathological examination is necessary. ${ }^{11}$ Other reasons for removal include presence of symptoms as well as requests from patients. ${ }^{12}$ Cervical polyps vary in size from $5 \mathrm{~mm}$ to $50 \mathrm{~mm} 7$. They are commonly cherry red to purplish red in colour, soft, pliable, fleshy, pedunculated, friable and readily bleeds on touch. ${ }^{13}$ Symptomatic polyps are more frequent in the premenopausal women while asymptomatic polyps are significantly more common in post-menopausal women. ${ }^{14}$

Cervical polyps result from chronic inflammation causing focal hyperplasia, reaction to foreign bodies, a localized 
congestion or cervical vasculature and/or an abnormal local response to estrogen stimulation. ${ }^{13,15}$ Endometrial polyps consist of endometrial glands, stroma and blood vessels. ${ }^{16}$

Many clinicians believe that routine removal of polyps is reasonable because they are easy to remove, unlikely to resolve, may become symptomatic and it is not known if they are likely to progress to malignancy. ${ }^{15}$ Mackenzie et al found no malignant features in 1366 cervical polyps and $67 \%$ of them were removed from asymptomatic women. ${ }^{7}$ This raises the question whether all polyps should be removed and subjected to histopathological examination, particularly in asymptomatic women. ${ }^{5}$ Removal of polyp is not without risks. The potential problems are risks of anesthesia, bleeding as well as infection. It is also shown that unnecessary removal of these polyps can have a significant impact on health care resources.

This study was done to analyse the spectrum of histopathological diagnosis in cases of cervical polyps and to identify focus of malignancy if present. This would help us to improve further management of cases of symptomatic and asymptomatic cervical polyps.

\section{METHODS}

This prospective study was conducted in the department of Obstetrics and Gynecology in a tertiary care teaching hospital over a period of two years. Women presenting with complaints of discharge per vaginum, inter menstrual bleeding, post coital bleeding and postmenopausal bleeding were subjected to a per speculum examination. Patients presenting with a polyp protruding through the cervix were included in this study.

Total of 107 women were detected with polypoidal growth protruding through the cervix. Informed written consent was taken. These women were subjected to a polypectomy and the specimen was sent for histopathological examination to the pathology department in $10 \%$ formalin. They were studied grossly and multiple sections taken. The specimens were processed in automated tissue processor. Four to six micron thick paraffin embedded sections were taken and stained by haematoxylin and eosin. The slides were examined under microscope by the pathologist and the various histopathological patterns identified and classified. Data was collected and shifted to computer for analysis. SPSS software was used for statistical analysis of data.

\section{RESULTS}

Total of 107 women were detected to have polypoidal growth protruding through the cervix. They were in the age group 22-70 years (Table 1). $47.7 \%$ of the women with cervical polyps were in the age group 40-49 years followed by $26.2 \%$ in the age group 30-39 years. Next common was in the age group 50-59 years (15\%) and $7.5 \%$ in the age group 20-29 years. No polyps were seen in patients below 22 years of age and there were only 4 cases in the age group 60-70 years.

Table 1: Age related frequency.

\begin{tabular}{|lll|}
\hline Age group & Frequency & Percentage \\
\hline 20-29 years & 8 & 7.5 \\
\hline 30-39 years & 28 & 26.2 \\
\hline 40-49 years & 51 & 47.7 \\
\hline $50-59$ years & 16 & 15 \\
\hline$\geq 60$ years & 4 & 3.7 \\
\hline Total & 107 & 100 \\
\hline
\end{tabular}

Table 2: Histopathological diagnosis of cervical polyps.

\begin{tabular}{|lll|}
\hline $\begin{array}{l}\text { Histopathology of } \\
\text { polyps }\end{array}$ & Frequency & Percentage \\
\hline Benign endometrial polyp & 23 & 21.5 \\
\hline $\begin{array}{l}\text { Endocervical mucous } \\
\text { polyp }\end{array}$ & 54 & 50.5 \\
\hline Leiomyomatous polyp & 14 & 13.1 \\
\hline $\begin{array}{l}\text { Endocervical glandular } \\
\text { polyp }\end{array}$ & 10 & 9.3 \\
\hline $\begin{array}{l}\text { Endometrial hyperplastic } \\
\text { glandular polyp }\end{array}$ & 06 & 5.6 \\
\hline Total & 107 & 100 \\
\hline
\end{tabular}

Endocervical mucous polyp was found to be the most common lesion $(50.5 \%)$. Next common was benign endometrial polyp $(21.5 \%)$, followed by leiomyomatous polyp in $13.1 \%$ and endocervical glandular polyp in 9.3\%. Endometrial hyperplastic glandular polyp was seen in $5.6 \%$ of patients. There were no foci of malignancy identified in any of these polyps.

All types of cervical polyps were more common in the age group 40-49 years. Cervical polyps were less commonly found in the age group $\geq 60$ years. Endocervical mucous polyp was the only type found in the age group 20-29 years whereas benign endometrial polyp was the only type of cervical polyp found in the age group $\geq 60$ years.

\section{DISCUSSION}

In our study, cervical polyps were more common in the age group 40 - 49 years $(47.7 \%)$ followed by 30-39 years (26.2\%). This is similar to reports where cervical polyps are more commonly seen in the reproductive age especially after 40 years of age. ${ }^{17-19}$ Tirlapur et al found maximum incidence of cervical polyp in the age group 25-45 years. ${ }^{12}$ Salim $S$ et al reported that more postmenopausal than pre-menopausal women are affected with endometrial polyps. ${ }^{20}$ Wachokor FNN et al found peak incidence of endocervical polyps in the fifth decade. ${ }^{21}$ In our study the most common finding was 
endocervical mucous polyps $(50.5 \%)$ followed by benign endometrial polyps $(21.5 \%)$, leiomyomatous polyp was next common (13.1\%) followed by endocervical glandular polyps $(9.3 \%)$ and endometrial hyperplastic glandular polyps $(5.6 \%)$.

Table 3: Histopathology of cervical polyp in relation to age.

\begin{tabular}{|llllll|} 
Age group & $\begin{array}{l}\text { Benign } \\
\text { endometrial } \\
\text { polyp }\end{array}$ & $\begin{array}{l}\text { Endocervical mucous } \\
\text { polyp }\end{array}$ & $\begin{array}{l}\text { Leiomyomatous } \\
\text { polyp }\end{array}$ & $\begin{array}{l}\text { Endocervical } \\
\text { glandular poly }\end{array}$ & $\begin{array}{l}\text { Endometrial } \\
\text { hyperplastic } \\
\text { glandular polyp }\end{array}$ \\
\hline 20-29 years & 0 & $8(14.8)$ & 0 & 0 & 0 \\
\hline $30-39$ years & $4(17.4)$ & $16(29.6)$ & $6(42.9)$ & $2(20)$ & 0 \\
\hline $40-49$ years & $9(39.1)$ & $22(40.7)$ & $8(57.1)$ & $6(60)$ & $6(100)$ \\
\hline $50-59$ years & $6(26.1)$ & $8(14.8)$ & 0 & $2(20)$ & 0 \\
\hline$\geq 60$ years & $4(17.4)$ & 0 & 0 & 0 & 0 \\
\hline Total & $23(100)$ & $54(100)$ & $14(100)$ & $10(100)$ & $6(100)$ \\
\hline
\end{tabular}

Sidhalingreddy et al and Sneha Sainy et al also found endocervical polyps as the most common type of polypoidal lesion followed by leiomyomatous polyps and fibroepithelial polyps. ${ }^{22,23}$ Nelson LA et al also found endocervical polyps $(57.1 \%)$ as the most common followed by inflamed endocervical polyps (21\%) and next most frequent-endometrial polyp $(6.2 \%){ }^{24}$ In our study there were no malignancy or dysplasia reported in the cervical polyps .Senturk MB et al Mackenzie I et al and Tirlapur SA et al also found no features of atypia, dysplasia or malignancy. ${ }^{7,12,25}$ This contradicts the findings of Berzolla $\mathrm{CE}$ et al who found a prevalence rate of $0.1 \%$ for malignancy and Schnatz PF et al who found the prevalence rate of $1.4-2.7 \%$ for any abnormality defined as atypia, dysplasia or malignancy. ${ }^{4,13}$ Mayada T.S .Younis et al found no case of overt malignancy in their series but $0.2 \%$ of polyps showed high grade cervical intraepithelial neoplasia in symptomatic patients. ${ }^{26}$ Detecting malignancy in uterocervical polyp is a rare event. Fauth $\mathrm{CI}$ et al reported benign and malignant utero-cervical polyp percentages as $95 \%$ and $1.4 \%$ respectively. ${ }^{27}$

\section{CONCLUSION}

Both our data and the review of literature suggest that the incidence of malignancy in endocervical polyp is very low. Hence it is suggested that in cases of asymptomatic polyp, there is a role for expectant management with no intervention after proper discussion with the patient and these patients can be followed up. Removing polyps only from symptomatic women and those with abnormal smears and doing histopathological examination of only these polyps would result in significant health resource savings.

Funding: No funding sources Conflict of interest: None declared

Ethical approval: The study was approved by the Institutional Ethics Committee

\section{REFERENCES}

1. Ozsaran AA, Itil IM, Sagol S. Endometrial hyperplasia coexisting with cervical polyps. Int $\mathbf{J}$ Gynecol Obstet. 1999;66:185-6.

2. Tiras. MB. Current diagnosis and treatment: Obstretics and gynecology. Chapter 40. Benign disorders of the uterine cervix. $11^{\text {th }}$ ed. Newyork NY: Lange (McGraw-Hill);2014:657-59.

3. Cortan RS, Kumar V, Collins T. Robbins Pathologic Basis of Disease. Female Genital Tract. $6^{\text {th }}$ ed. Philadelphia, PA: Elsevier; 1992:1042-8.

4. Berzolla CE ,Schnatz PF , O'Sullivan DM, Bansal R, Mandavilli S ,Sorosky JI. Dysplasia and malignancy in endocervical polyps. J Womens health (Larchmt). 2007;16(9):1317-21.

5. Abramovici H, Bornstein J, Pascal B. Ambulatory removal of cervical polyps under colposcopy. Int $\mathbf{J}$ Gynaecol Obstet.1984;37(1):47-50.

6. Golan AI, Ber A, Wolman I, David MP. Cervical polyp: Evaluation of current treatment. Gynecol Obstet Invest. 1994;37(1):56-8.

7. Mackenzie IK, Naish C, Rees CM, Manek S. Why remove all cervical polyps and examine them histologically? BJOG. 2009;116(8):1127-9.

8. Medline Plus Medical Encyclopaedia. August 2009 http://www.nlm.nih.gov/medlineplus/ency/article/00 1494.htm

9. GP notebook. Cervical polyp.2007 http://www.gpnotebook.co.uk/cathe/-16239 16541.htm.

10. National patient pathways. Management of cervical polyps. (http://www.pathways.scot.nhs.uk/polyps.htm )

11. Selim MA, Shalodi AD. Benign diseases of uterine cervix. Ruling out neoplasia a diagnostic priority. Postgrad Med. 1985 Jul;78(1):141-3.

12. Tirlapur SA, Adeyemo A, O'Gorman N, Selo-Ojeme D. Dan selo-ojeme. Clinico-pathological study of cervical polyps. Arch Gynecol Obstet. 2010;282:535-8 
13. Schnatz PF, Ricci S, O'Sullivan DM. Cervical polyps in postmenopausal women: is there a difference in risk? .Menopause. 2009;16:524-8.

14. Neri A, Kaplan B, Rabinerson D, Ovadia J, Braslavsky D. Cervical polyp in the menopause and the need for fractional dilatation and curettage. Eur J Obstet Gynecol Reprod Biol. 1995;62:53-5.

15. Berzolla CE, Schnatz PF, O'Sullivan DM, Bansal R, Mandavalli S, Sorosky JI. Dysplasia and malignancy in endocervical polyps. J Womens Health. 2007; 16:1317-21.

16. Peterson WF, Novak ER. Endometrial polyps. Obstet Gynecol.1956;8:40-9.

17. Pallipady A, Illanthody S, Vaidhya R, Ahmed Z, Suvarna R, Metkar G et al. A clinic-morphological spectrum of non-neoplastic lesions of the uterine cervix at AJ-hospital Mangalore. J Clini Diagnos Res. 2011;5:546-50.

18. Jones MA, Young RH. Atypical oxyphilic metaplasia of the endocervical epithelium: A report of six cases. Int J Gynecol Pathol.1997; 16:99-102.

19. 19.Nigatu B , Gebrehiwot Y, Kiros K, Eregete W.A five year analysis of histopathological results of cervical biopsies examined in a pathology department of a teaching hospital (2003-2007). Ethiop J Reprod Health. 2010;4:52-7.

20. Salim S, Won H, Nesbitt-Hawes E, Campbell N, Abbott J. Diagnosis and management of endometrial polyps: a critical review of the literature. J Minim Invasive Gynecol. 2011;18(5):569-81

21. Nwachokor FN, Forae GD. Morphological spectrum of non-neoplastic lesions of the uterine cervix in
Warri, South-South, Nigeria. Niger J Clin Pract. 2013;16(4):429-32.

22. Sidhalingreddy, Biradar S, Akhila, Domble VD. Clinicopathological analysis of polypoid lesions of cervix. J Evol Med Dent Sci.2013;2(15):2563-70.

23. Saini S, Kanetkar SR. Histopathological study of lesions of uterine cervix. J Evid Based Med Healthc. 2016;3(103):5685-94.

24. Nelson AL, Papa RR, Ritchie JJ. Asymptomatic cervical polyps: can we just let them be? Women's Health. 2015;11(2):121-6.

25. Senturk MB, Budak MS, Durukan OB, Cakmak Y, Yildirim A, Polat M. Clinicopathological evaluations of cervical polyps. Zeynep Kamil Tip Bulteni. 2015;46:98-101.

26. Younis MT, Iram S, Anwar B, Ewies AA. Women with asymptomatic cervical polyps may not need to see a gynaecologist or have them removed: an observational retrospective study of 1126 cases. Europ J Obstet Gynecol Reprod Biol. 2010;150:1904.

27. Fauth CI, Franko A, Duan Q, Wood S, Duggan MA. Clinicopathological determinants of vaginal and premalignant-malignant cervico-vaginal polyps of the lower female genital tract. J Low Genit Tract Dis. 2011;15(3):210-8

Cite this article as: Gopalan U, Rajendiran S, Karnaboopathy R. Clinicopathological analysis of cervical polyps. Int J Reprod Contracept Obstet Gynecol 2017;6:1526-9. 